\title{
The Potential and Status of Renewable Energy Development in Malaysia
}

\author{
Wan Syakirah Wan Abdullah ${ }^{1, *}$, Miszaina Osman ${ }^{2}$, Mohd Zainal Abidin Ab Kadir ${ }^{2,3}$ \\ and Renuga Verayiah ${ }^{2}$ \\ 1 TNB Renewables Sdn. Bhd.(TRe), Level 31, PJX-HM Shah Tower, 16A Persiaran Barat, \\ 46050 Petaling Jaya, Selangor, Malaysia \\ 2 Institute of Power Engineering (IPE), Universiti Tenaga Nasional, Jalan IKRAM-UNITEN, \\ 43000 Kajang, Selangor, Malaysia; miszaina@uniten.edu.my (M.O.); zainal@uniten.edu.my (M.Z.A.A.K.); \\ renuga@uniten.edu.my (R.V.) \\ 3 Advanced Lightning, Power and Energy Research Centre (ALPER), Department of Electrical and Electronic \\ Engineering, Universiti Putra Malaysia, 43400 Serdang, Selangor, Malaysia \\ * Correspondence: syakirahwa@tnb.com.my; Tel.: +60-193-856-580
}

Received: 28 April 2019; Accepted: 24 May 2019; Published: 25 June 2019

check for updates

\begin{abstract}
The Malaysian Government has set an ambitious target to achieve a higher penetration of Renewable Energy (RE) in the Malaysian energy mix. To date, Malaysia has approximately 2\% of its energy coming from RE generation sources compared to the total generation mix and targets achieving $20 \%$ penetration by 2025 . The current energy mix for Malaysia power generation is mainly provided by natural gas and coal. The discussion will cover the traditional sources of generation including natural gas, coal and big hydro stations. In addition, the paper will cover in depth the potential of RE in the country, challenges, and opportunities in this sector. This study can give an initial evaluation of the Malaysian energy industry, especially for RE and can initiate further research and development in this area in order to support the Government target to achieve RE target of $20 \%$ by 2025 .
\end{abstract}

Keywords: renewable energy; conventional energy; Malaysia; renewable energy potential; energy policies

\section{Introduction}

Tenaga Nasional Berhad (TNB), the incumbent utility company in Malaysia has set up a subsidiary known as TNB Renewables Sdn. Bhd. (TRe) in line with the company's goal of being among the top 10 utility companies in the world under a transformation program named Reimagining Tenaga. TRe covers several segments to grow RE in the local market, including Large Scale Solar (LSS) which is categorized as being projects larger than $30 \mathrm{MW}$, small scale RE projects below $30 \mathrm{MW}$ including Biomass and biogas projects, retail self-generation focusing on roof top solar, and emerging technologies such as Battery Energy Storage Systems (BESSs), as well as Microgrids and Virtual Power Plant (VPPs). TRe is an investment company and also an asset owner for all RE plants in the local market for TNB. TRe is also seen as a catalyst to achieve the government's RE target. Figure 1 shows the penetration of solar and wind power in the top 10 countries in the world, which are mostly from European region, while Malaysia at this point of time only has $2 \%$ of RE penetration, which mostly is provided by solar Photovoltaic (PV). 


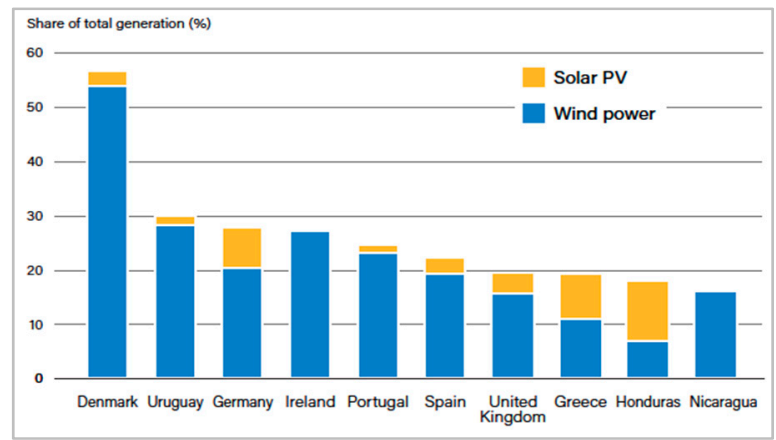

Figure 1. Share of power generation from renewable energy, top 10 countries in 2017. Reproduced with permission from [1]. Renewable Energy Policy Network for the 21st Century, 2018.

Coal, natural gas and large hydro have been the main sources of power generation in Malaysia [2,3]. For nuclear power, Malaysia has been quite consistent with the decision not to include this technology as one of the power generation sources in the country. Public acceptance towards this technology is relatively low, and the main concerns are radioactive waste handling and the impacts on environment and community [4-7].

For research development on renewable energy in Malaysia, there is significant growth in terms of research publication in this area as analyzed by SCOPUS, the largest abstract and citation database of peer-reviewed literature in Figure 2. This shows that RE has significantly caught the attention of researchers to understand the potential, issues and opportunities in this area. Around 100 relevant documents were published recently focusing on Malaysia. In comparison with the search keywords of renewable energy in Europe, 400 documents were produced. This roughly indicates that the RE research and development in Malaysia is still in progress and a lot of potential remains to be tapped. The discussion in this paper will open up research and project development opportunities in RE segments in Malaysia, since Malaysia is among the most developed countries in the Association of Southeast Asian Nations (ASEAN) and has an ambitious target in the RE sector [8,9].

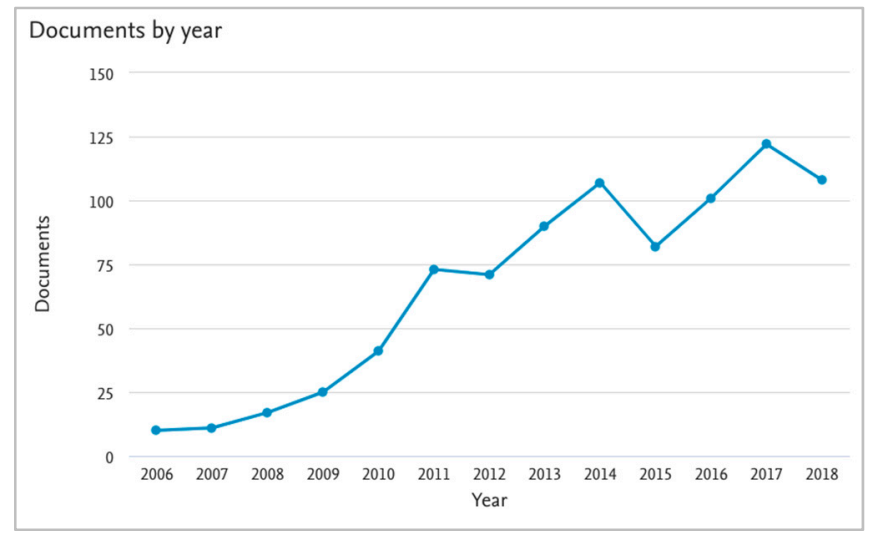

Figure 2. Scopus analysis search results for renewable energy and Malaysia keywords.

In terms of greenhouse gas (GHG), Malaysia intends to reduce the GHG emissions intensity of GDP by $45 \%$ by 2030 relative to 2015 numbers. The GHG intensity level improved by $27 \%$ in 2014 compared to 2005, where the level in 2014 was at the equivalent of 317.63 Metric Tonnes (Mt) of Carbon Dioxide $\left(\mathrm{CO}_{2}\right)$ and net emissions were at $50.48 \mathrm{Mt}$. In the eleventh Malaysia Plan (2016-2020), it is outlined that the focus is to reduce the national dependency on fossil fuels while ensuring the development of reliable and affordable energy resources. The execution of the Renewable Energy Act 2011 and the implementation of the Feed-in Tariff (FiT) scheme demonstrated the aim of the country to explore and deploy RE as part of its national energy mix [10]. 


\section{Conventional Generation}

Traditionally, Malaysia is dependent on conventional power generation, including natural gas, coal and large hydro [11]. Figure 3 shows the difference in the fuel source for power generation. Moving forward the government is aiming to increase power generation from RE sources [11-13]. This can include solar power, wind, biomass, biogas, BESS systems and VPPs [14].

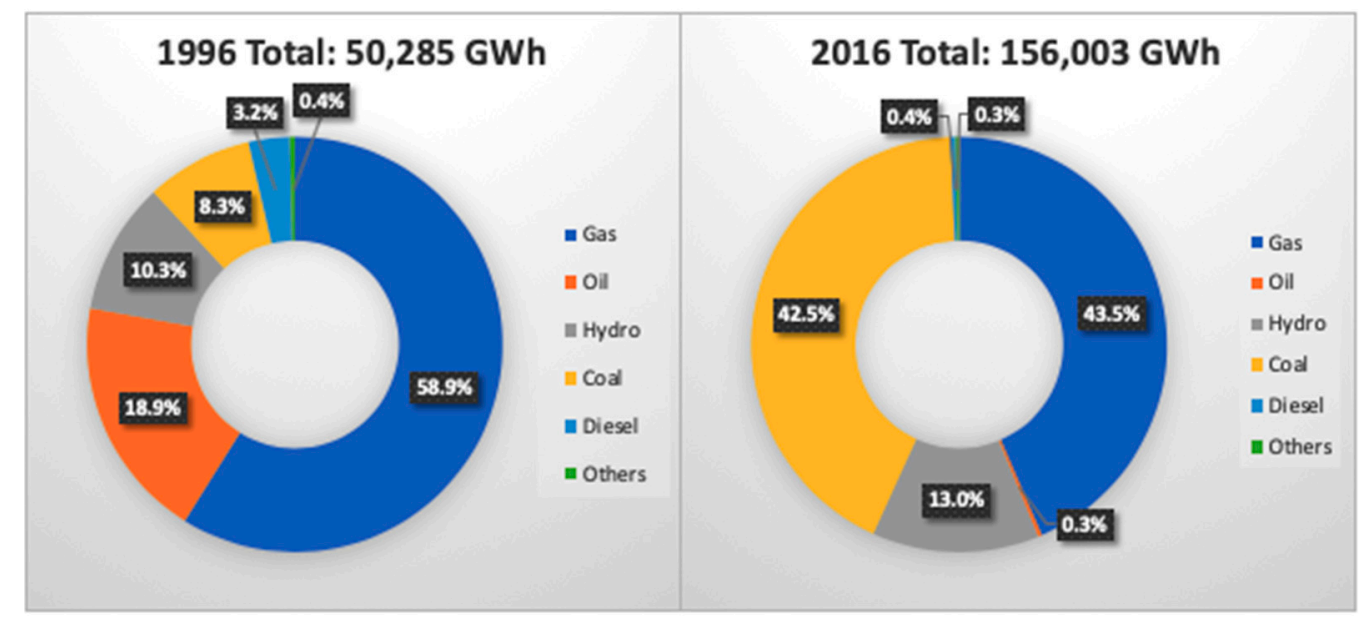

Figure 3. Malaysia power generation fuel source. Reproduced with permission from [15]. Energy Commission of Malaysia, 2017.

\subsection{Natural Gas}

Malaysia is blessed with natural resources. Natural gas demand in Malaysia in 2015 was 943,154 Million Metric Standard Cubic Meters Per Day (MMSCFD). The largest users out of this number come from the power sector, which contributes 54.3\% [16]. Most gas power stations are connected with pipeline gas. Commercially, power sectors are charged with a subsidized gas price of RM 27.20/mmbtu for the first $1000 \mathrm{mmbtu}$ and the remaining balance is be charged using the market LNG price. The total cost of fuel for power generation is passed through to customers via a mechanism called the Imbalance Cost Pass Through (ICPT) that translates actual fuel cost to customer tariffs. The whole tariff setting mechanism is called Incentive Based Regulations (IBR). Starting in 2014, the IBR mechanism was introduced to promote transparency in tariff mechanisms [17].

\subsection{Coal}

Coal as the cheapest type of fossil fuel normally has a role in the energy mix. But countries like Germany are reducing coal contribution in the energy mix when they embarked on RE energy policy targeting carbon neutrality by 2050. Coal is the largest fuel source for power generation in peninsular Malaysia. Most of the coal plants are used as base load plants. Malaysia owns large coal power plants of up to $1000 \mathrm{MW}$ each per plant. These plants also in terms of operations are partly used for spinning reserves. In 2016, coal plants contributed $42.5 \%$ from the total generation mix, as shown in Figure 3. As mentioned earlier, the main motivation for coal plant ups is mainly driven by the relatively low cost offered by this type of fuel. Moving forward, with the government's target and reducing cost of RE, it is forecasted that the cost from RE generation especially solar will decrease below the price of coal generation $[18,19]$.

\subsection{Large Hydro}

Malaysia has a lot of natural hydro resource potential [20]. This is mainly provided by its unique geographical advantage, as Malaysia has 189 rivers with the total length approximately of $57,300 \mathrm{~km}[21,22]$. Hydro power generation contributed $13 \%$ of total Malaysian power generation in 
2016. Most hydro power stations that are more than $30 \mathrm{MW}$ were developed by the incumbent utility company, which has recently completed Hulu Terengganu (250 MW) and Ulu Jelai (382 MW) in the state of Pahang. Small hydro stations below $30 \mathrm{MW}$ operate in a liberalized market, meaning they are open for any private developer and are mostly are incentivized by a Feed-in Tariff (FiT) mechanism managed by the Sustainable Energy Development Authority (SEDA) Malaysia [23]. As of January 2017, small hydro power stations below 30 MW under FiT contribute up to $200 \mathrm{MW}$ of Malaysian energy generation. Most of the hydro plants in the system are used as peaking plants and the resources are carefully planned to take high water levels into consideration of during the monsoon season.

\section{Renewable Energy in Malaysia}

Renewable energy in Malaysia has gone a long way since 1980 when Malaysia embarked on the Four Fuel Diversification Strategy which aimed to balance the utilization of oil, gas, coal and hydro in the energy mix. In 1997, the Kyoto Protocol was signed and Fifth Fuel Policy was signed in 1999 [24-26]. Malaysia committed to COP 15 to reduce its carbon emissions by $40 \%$ [27], and Malaysia pledged to reduce its Green House Gas (GHG) emissions contribution to its Gross Domestic Product (GDP) by $45 \%$ in 2030 relative to 2005 [10,28-30].

Recently in 2011, Renewable Energy Act was gazetted and also the implementation of Feed-in Tariffs (FiT) occurred to expedite growth in the RE sector. Finally, in 2018, the government targeted the achievement of $20 \%$ of RE in the energy mix by the year 2025 . The evolution of policies shows the commitment from the government towards implementing RE in the country [31,32]. This is also supported by the launch of Incentive Based Regulation (IBR) in 2014 which aims to reduce fuel subsidies in a structured manner [33,34]. RE in this context covers solar, wind, biomass, biogas, mini-hydro and other applications of Distributed Energy Resources (DER) including BESS systems. Next, this paper will discuss in detail the RE market and its potential in Malaysia.

\subsection{Solar Potential}

Malaysia has among the highest potential for solar uptake as it is strategically located near the equator. Monthly solar irradiation for Malaysia is estimated at $400-600 \mathrm{MJ} / \mathrm{m}^{2}$ [35]. The irradiation is higher during North-East monsoon when the wind direction coming from central Asia to South China Sea through Malaysia and finally to Australia between November and March. Lower irradiation during South-West monsoon when the wind direction changes and proceeds from Australia and moves towards Sumatera Island before reaching the Straits of Malacca between May and September [35]. Generally, Malaysia has a high potential for solar generation taking into consideration its hot and sunny weather all year round [36]. Estimated potential for solar generation can reach up to $6500 \mathrm{MW}$ [18]. Hence, Large Scale Solar (LSS) and rooftop solar is a good choice for solar deployment in Malaysia [11].

\subsubsection{Large Scale Solar (LSS)}

The Energy Commission (EC) of Malaysia has started the competitive bidding process for LSS since 2016, offering a total of 434 MW for Peninsular Malaysia with a levelized tariff ranging from 39.95 to $44.95 \mathrm{sen} / \mathrm{kWh}$. The incumbent utility company has won $50 \mathrm{MW}$ for the first round of the LSS bidding exercise and has successfully commissioned the Sepang LSS plant in November 2018. The second round of LSS bidding by EC offers $563 \mathrm{MW}$ in total and an estimated $500 \mathrm{MW}$ for the third round of bidding in 2019. For the second round of bidding, TNB has secured 30 MW that will be built in Kedah, Malaysia. The third round of LSS in 2019 started in February 2019 with a total offered capacity of $500 \mathrm{MW}$ and up to $100 \mathrm{MW}$ of capacity limitation for each developer.

Large scale solar is seen as a transparent mechanism for awarding LSS projects in order to achieve the government's RE target. The generation mix for peninsular Malaysia in Figure 4 shows the percentage of solar and other RE projects in the generation mix until the year 2026 [15]. 


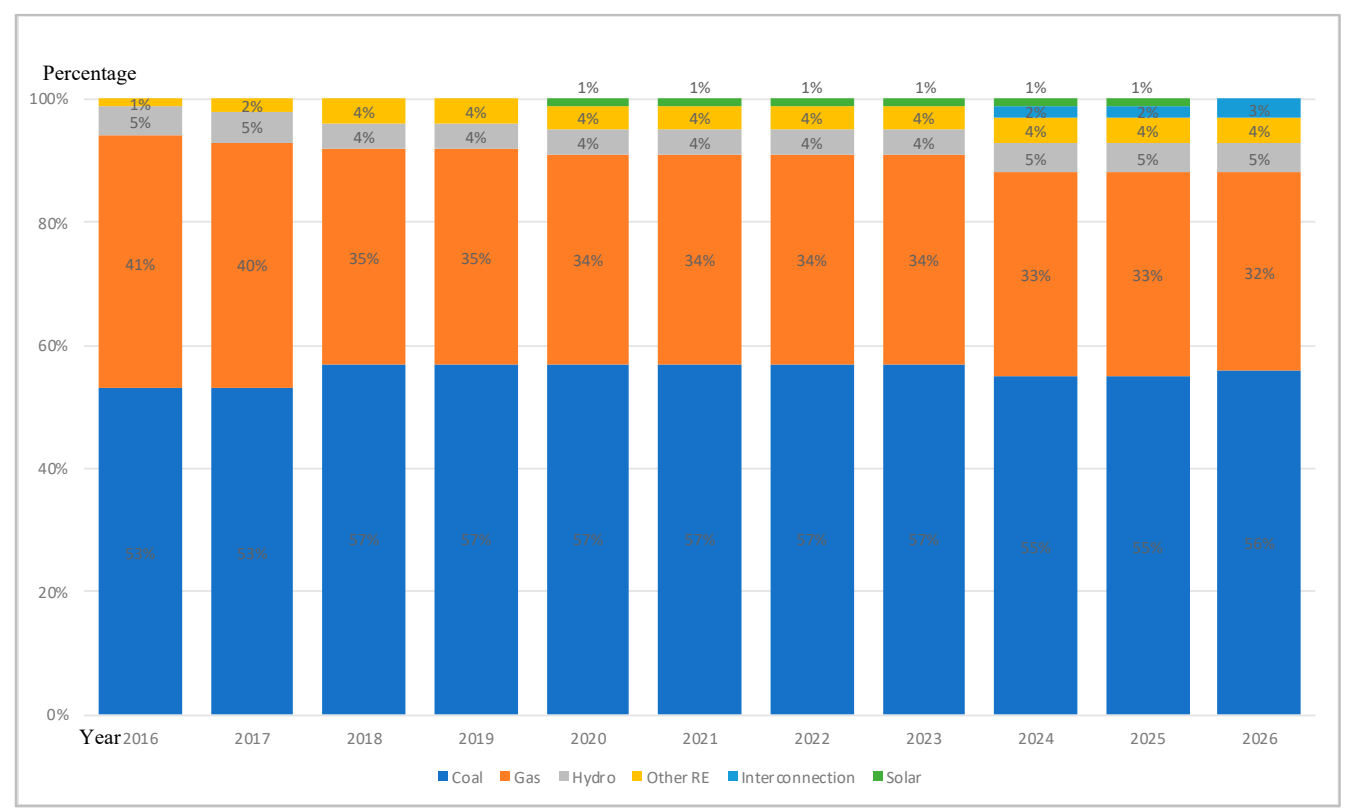

Figure 4. Generation percentage mix in peninsular Malaysia. Reproduced with permission from [15].

Energy Commission of Malaysia, 2017.

From the first 50 MW LSS project for TNB, and among the pioneer large scale solar operating in Malaysia, several challenges have been identified during construction and operation, including changes in requirements during bids and construction, delays in getting approval from approving authorities that lead to additional costs being incurred, and delays in work progress. As a pioneer in constructing this kind of plant, with a tight project schedule, and limited experience in construction, the project team is susceptible to requiring long working hours and facing project quality issues. At the same time, fluctuations in the local currency can lead to a higher project cost.

From the total capacity awarded by EC in the first and second round of LSS in Figure 5, most of the capacity is located in Perlis, which is 3996 MW or $87 \%$ of total awarded capacity of the first and second phases of LSS bidding. This is because Perlis is the highest state with the high solar irradiance, providing this state with good potential to harvest solar energy [35].

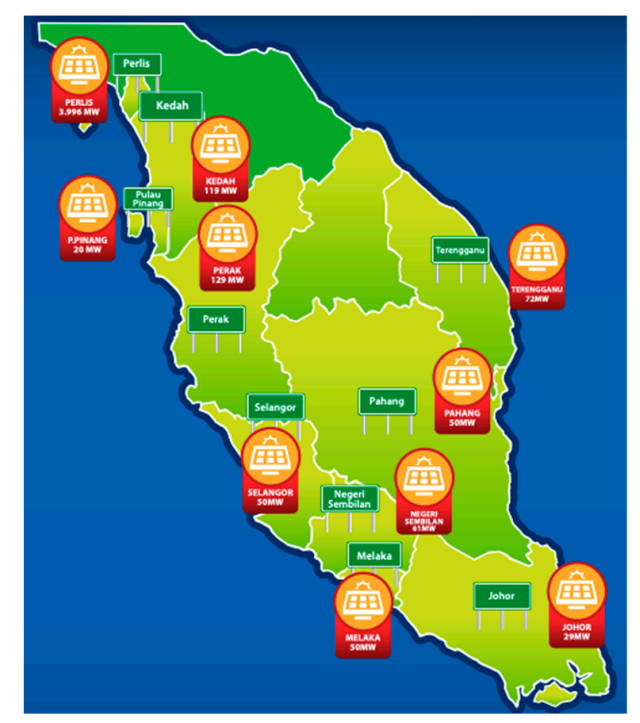

Figure 5. Solar capacity awarded in the first and second round of LSS bidding. Reproduced with permission from [15]. Energy Commission of Malaysia, 2017. 


\subsubsection{Rooftop Solar}

Rooftop solar is another segment in solar power generation that has been recently introduced in Malaysia. Recently the launching of leasing packages for rooftop solar has attracted customers to put solar panels on the rooftops of their buildings. Signing up for attractive packages such those requiring zero capital can promote and incentivize buyers to invest into such plans that will give benefits in terms of bill savings to customers [37-40].

The solar leasing program offers zero capital cost requirements that make it more attractive for customers to install rooftop solar. Besides that, the packages offered include end-to-end hassle-free services during the design, commissioning and operation periods. The installation of rooftop solar can potentially reduce the monthly bill by committing to one fixed tariff offered by solar leasing companies. Since this tariff is fixed, it is shielded from any tariff hike for the tenure of the agreement. Historically, tariffs in Malaysia increased at a rate of $4.5 \%$ year-on-year. There are also other types of financing structures available besides leasing. This includes outright purchases, loans from financing institutions, and Solar Power Purchase Agreements (SPPAs). Customers also will be automatically signed up for Net Energy Metering (NEM) which the government announced as part of the new NEM mechanism in 2018.

\subsubsection{New Net Energy Metering (NEM) Mechanism}

Prior to the new NEM mechanism that was introduced in 2018, the NEM mechanism was designed to remunerate participants by using a displaced cost at $31 \mathrm{sen} / \mathrm{kWh}$ while the purchasing power price is over $50 \mathrm{sen} / \mathrm{kWh}$. Starting from 2019, the NEM mechanism offers the same tariff for selling and buying electricity for NEM participants. This new mechanism is anticipated to attract more customers to install rooftop solar and register with NEM. The quota for this mechanism is up to $500 \mathrm{MW}$ on a first come first serve basis.

For commercial and industrial customers, the solar capacity limit is based on $75 \%$ of Maximum Demand (MD), while for low voltage customers, the limit is up to $60 \%$ of the current transformer rating or $60 \%$ of the fuse rating. For residential customers, houses with three-phase system, the limit is up to $72 \mathrm{kWp}$ while for a single-phase system, the limit is $12 \mathrm{kWp}$. NEM credits will be in $\mathrm{kWh}$, which is different from the previous NEM, the credit is in Ringgit Malaysia. Customers are able to keep any credit produced if the energy generated by the solar rooftop is more than the premise electricity consumption. The credit in terms of kWh will be valid up to 24 months before it is expired.

\subsection{Smart Meter Deployment}

Smart meters are one of the enablers of NEM implementation. Smart meters are capable of measuring, recording and transmitting data for analysis of the energy consumption. Smart meters can also be used by the utilities to detect a fault in the system and plan for recovery management during outages [41,42]. With a smart meter, a defective meter can be detected more quickly and sent to the utility for faster restoration, and at the same time customers can be informed about the status of the power grid. Furthermore, smart meters can reduce the frequency and duration of outages by providing tools for better and more accurate planning and asset management [41].

The incumbent utility is embarking on a pilot deployment of smart meters in the state of Melaka and Putrajaya. RM 18.8 billion has been allocated under the second Regulatory Period for investment in Transmission and Distribution assets. From this amount, RM 2.7 billion will be invested into future technologies for the grid. The deployment of smart meters covers 340,000 smart meters in Melaka and 1.2 million in Klang Valley [43]. With the deployment of smart meters, it is more convenient for customers to install rooftop solar as this technology requires metering capability to capture data. Smart meters are an enabler for solar rooftop deployment where battery energy storage can be an additional feature to complement the intermittency effect of solar generation and also taking advantage of peak demand reduction and energy arbitrage that can potentially provide bill savings to customers. 


\subsection{Wind Power Potential}

Wind power is another type of RE potential in Malaysia. Malaysia can be considered as a low wind speed area compared to other countries. Generally, strong wind in Malaysia is blown from the Indian Ocean and the South China Sea. Monthly mean wind speed is between 1.5 and $4.5 \mathrm{~m} / \mathrm{s}$. Higher altitude areas can harness between 9 to $11 \mathrm{~m} / \mathrm{s}$ of wind power. In peninsular Malaysia, Mersing, Johor and Kuala Terengganu have been identified as high wind areas while in East Malaysia, Kudat and Sabah are the highest wind potential areas. Onshore wind power in Malaysia could reach up to 1.5 MW [44-46].

Malaysia also has the potential for offshore wind power which has not been tapped. Wind blowing from the South China Sea will normally occur during the monsoon season in November to February [47]. Detailed historical data of wind have to be analyzed in a specific site to ensure the viability of the project. Based on findings from previous studies, Mersing and Kudat are considered as potential sites with averages of $3 \mathrm{~m} / \mathrm{s}$ at 60 meter heights [48]. Generally, the southern part of peninsular Malaysia has more wind potential and more wind in the month of January due to the monsoon season [44].

Support and incentives from the Government is required at the initial stage of deployment of wind power in Malaysia, as this is a capital-intensive investment. For instance, at this point of time, the absence of wind power technology in the Feed-in Tariff categories make it difficult to achieve project viability. This exacerbates the issue of low wind for Malaysia. Suitable technology for low wind conditions should be explored in Malaysia to harness the untapped potential of wind power.

\subsection{Biogas}

Biogas is normally produced by the Anaerobic Digestion (AD) process. It refers to a system where it processes the organic material from waste to produce biogas that can be used to generate electricity $[49,50]$. It is also a potential option to decrease the use of fossil fuels for power generation [50-53]. Biogas plants can be fed by several potential sources, including organic municipal waste, food waste, sewage as an individual feedstock source or a co-digestion process where a combination of more than one source can yield a higher biogas volume [54,55]. Potential feedstock to generate biogas in Malaysia include Municipal Solid Waste (MSW) [56], food waste, cattle manure, sewage and the most established waste product for biogas in Malaysia, which is palm oil mill effluent (POME) [57-64].

Biogas potential from cattle manure, POME and landfill sources by regions in peninsular Malaysia are tabulated in the table below. The southern region covers Johor, Melaka and Negeri Sembilan, the central area covers Selangor and Kuala Lumpur and the northern region covers Perak, Penang, Kedah, Perlis. The east Coast region covers Pahang, Terengganu, and Kelantan.

From the data collected, the potential energy generation from biogas is calculated and tabulated in Tables 1 and 2. Table 1 is the potential in terms of biogas yield while Table 2 in terms of energy generated. The result shows that most potential coming from POME sources. This is because POME comes from palm oil and has established a huge market in Malaysia. At the moment there are more than 10 plants in Malaysia generating electricity using biogas and biogas engines. Biogas can also be transformed into other sources of energy such as heat and power (co-generation) and biomethane.

Table 1. Potential of biogas feedstock in terms of biogas yield. Reproduced with permission from [65]. IEEE, 2018.

\begin{tabular}{c|ccc}
\hline & Cattle Livestock & POME & Landfill \\
\hline Region & Biogas yield (m³/day) & $\begin{array}{c}\text { Total Chemical Oxygen } \\
\text { Demand (tonne/year) }\end{array}$ & $\begin{array}{c}\text { Captured } \mathrm{CH}_{4} \\
\text { (tonne/year) }\end{array}$ \\
South & 236,837 & 604,611 & 159 \\
North & 623,041 & 371,540 & 174 \\
East & 173,796 & 560,490 & 105 \\
Centre & 43,128 & 81,475 & 245 \\
Total & $1,076,802$ & $1,618,116$ & 683 \\
\hline
\end{tabular}


For heat production, biogas is burnt in a boiler and the heat can be used for steam production. This option is suitable for industrial plants or large scale heat consumers. For combined heat and power generation, biogas is used in Combined Heat and Power (CHP) plants, which produce electricity and heat. Finally, for biomethane, biogas is treated with a method where $\mathrm{CO}_{2}$ is removed until the $\mathrm{CH}_{4}$ concentration is $96 \%$ or higher. Biofuel has its own market where it can be injected into natural piped gas, transported via several mechanisms or can be used as a raw material in the chemical industry or as a combustible for fuel cells.

Table 2. Potential of power generation potential from biogas. Reproduced with permission from [65]. IEEE, 2018.

\begin{tabular}{|c|c|c|c|c|}
\hline & Cattle Livestock & POME & Land Fill & \\
\hline Region & $\begin{array}{c}\text { Potential Energy } \\
\text { Generation (MWh) }\end{array}$ & $\begin{array}{c}\text { Potential Energy } \\
\text { Generation (MWh) }\end{array}$ & $\begin{array}{c}\text { Potential Energy } \\
\text { Generation (MWh) }\end{array}$ & $\begin{array}{c}\text { Total Potential Energy } \\
\text { Generation (MWh) }\end{array}$ \\
\hline South & 646 & 887,602 & 994 & 889,242 \\
\hline North & 413 & 545,441 & 1,081 & 546,523 \\
\hline East & 474 & 822,830 & 669 & 823,973 \\
\hline Centre & 118 & 119,610 & 1,517 & 121,299 \\
\hline Total & 1650 & $2,375,484$ & 4262 & $2,381,038$ \\
\hline
\end{tabular}

For Municipal Solid Waste (MSW), several main issues related to waste management contribute to the implementation of biogas projects for power generation from MSW. From the laboratory exercise conducted by various government agencies in 2015, it was highlighted that several key enablers are crucial to ensure the sustainability of this sector. The suggestions include to strengthen enforcement on preventing littering, illegal dumping and the separation of waste at the source. It is also worth considering food waste as one of the highest potential sources for biogas production. It is estimated that more than $40 \%$ of Malaysian MSW is food waste. High organic content in the food waste means this source has a high potential to be tapped. The government of Malaysia also is targeting a $40 \%$ diversion of total of tonnage of waste from landfill by 2020. The Malaysian recycling rate is around $11 \%$ compared to other countries like South Korea (49\%), Germany (33\%), Australia (33\%), Canada (27\%) and the United Kingdom (17\%) [66].

The analysis indicates that there is a huge potential for biogas generation. Anyhow, Malaysia lacks aggressive policies to expedite the implementation and improper waste management, such clear policies and enforcement on the separation of waste at the source, which hinders successful implementation of such projects. Another factor to be considered is the location of biogas plants. The further the location is from the nearest connection point to export generated power, the more that the project's viability is reduced unless the biogas and power generated are used for self-consumption.

\subsection{Biomass}

Malaysia produces approximately 168 million tons of biomass, including resources from palm oil waste, rice husks, coconut waste, sugar cane waste, municipal waste and forestry waste [67]. Malaysia being the largest palm oil producer in the world has huge potential resources from biomass. Biomass has an advantage over other types of RE in terms of availability and huge resources, plus this type of resources can easily be stored. In terms of RE technology deployment via the FiT mechanism in Table 3, biomass has shown significant deployment status compared to other technologies which is approximately $17 \%$ of total deployment. In terms of potential, biomass potential in Malaysia can generate up to $2400 \mathrm{MW}$ [67].

Biomass has potential for the pelleting conversion process and has attractive potential for co-firing in conventional power plants, which traditionally use coal or natural gas. This is a huge benefit and advantage in terms of using waste for electricity generation. Co-firing offers several environmental benefits such as reducing the carbon dioxide, Sulfur Oxides (SOx) and Nitrogen Oxides (NOx) emissions that can reduce the GHG level. Other than that, if this technology is compatible and feasible for 
deployment, it can offer additional benefits such offering energy security. This is because part of the fuel can come from local resources compared to coal which is mainly an imported resource for Malaysia. Co-firing with biomass also can potentially reduce electricity generation cost due to a lower biomass pallet price compared to coal and natural gas. Although huge benefits can be demonstrated, it will also provide some negative impact on the efficiency of the power plant machinery, cause corrosion for boilers and generate fly ash [68].

The recent issue of the Malaysian palm oil ban from the European Union (EU) may have impacted the supply and demand of this commodity. Malaysia practices sustainability in managing palm oil. Furthermore, most of the deforestation is contributed by beef production industries and not by any other agriculture activities, as claimed by the EU regarding this matter [69]. Malaysia as the second largest country producing palm oil after Indonesia has a huge source of waste from palm oil that can potentially be used for biomass.

Table 3. Installed capacity (MW) of commissioned RE installations. Reproduced with permission from [70]. Sustainable Energy Development Authority, 2018.

\begin{tabular}{|c|c|c|c|c|c|c|}
\hline & Biogas & Landfill & Biomass & Hydro & Solar PV & Total \\
\hline 2012 & 2 & 3.16 & 45.8 & 11.7 & 31.54 & 94.2 \\
\hline 2013 & 3.38 & 3.2 & 0 & 0 & 106.88 & 113.46 \\
\hline 2014 & 1.1 & 0 & 12.5 & 0 & 61.87 & 75.47 \\
\hline 2015 & 0 & 5.4 & 20.8 & 6.6 & 60.33 & 93.13 \\
\hline 2016 & 0 & 15.46 & 19.5 & 12 & 77.83 & 124.79 \\
\hline 2017 & 0 & 22.54 & 0 & 0 & 38.47 & 61.01 \\
\hline 2018 & 0 & 11.71 & 5.85 & 20 & 2.32 & 39.79 \\
\hline Cumulative & 6.48 & 61.47 & 104.45 & 50.3 & 379.15 & 601.85 \\
\hline
\end{tabular}

\subsection{Small Hydro}

Malaysia is rich in hydro potential, with high temperature and humidity all year round plus a high rainfall volume. These factors make Malaysia one of the largest hydropower potential areas. Small hydro plants which are sometimes referred to as mini-hydro in Malaysia are categorized as bing under $30 \mathrm{MW}$. The smaller scale from $5 \mathrm{~kW}$ to $500 \mathrm{~kW}$ is called Micro Hydro. In Malaysia, there is still a lot more untapped potential for small and micro hydro [71-73]. Small hydro also is considered the cleanest energy form, as the GHG amount emitted is far lower compared to large scale hydro [73]. The adoption of small hydro in Malaysia is supported by the government via the Feed-in-tariff. Under the FiT mechanism, the small hydro plants are able to sell power generation to TNB via execution of a RE Power Purchase Agreement (REPPA). The FiT rate for small hydro is 26 sen for generation $2 \mathrm{MW}$ and below, 25 sen for $2 \mathrm{MW}$ to $10 \mathrm{MW}$ and 24 sen for above $10 \mathrm{MW}$ up to $30 \mathrm{MW}$. The table below shows the latest amount of RE power generated under the FiT system in MWh.

TNB is traditionally the developer for large hydro in Malaysia, including the Kenyir Hydro Power Station in Terengganu, Sungai Perak Hydro Scheme consists of Temenggor, Bersia, Kenering, Chenderoh, Sungai Piah Hydro Power Stations in Perak, Cameron Highland Hydro Power Stations in Pahang and Pergau in Kelantan. From previous experiences in developing hydropower stations in Malaysia, several challenges and risks have been identified. This includes ensuring the site selected has enough water capacity for the targeted energy generated, as well as sedimentation issues that might affect the performance of the machines. Hydrology studies have to be conducted thoroughly. Besides that, a construction capital cost overrun can impact the entire economics of the project. Cost overrun can be caused by unexpected earthwork costs or substantial amounts being claimed by stakeholders of the projects, including resettlement of original residence of that project area. With the uncertainty in the project costs, more attractive FiT rates will boost uptake in the development of small hydro in Malaysia. 


\subsection{Battery Energy Storage Systems (BESSs)}

Battery Energy Storage Systems (BESSs), Virtual Power Plants (VPPs) and microgrids are part of another area that can contribute to the development of RE in Malaysia. With the emerging of Renewable Energy in the system, the support from BESS will be crucial at a certain point of penetration. Based on studies, at the level of $20 \%$ targeted by the Malaysian government, support from batteries in the system is needed [74-76].

BESS is capable of supplying services across many applications in the power system. These include Frequency Regulation [77], Voltage Support, Spinning Reserve and Black Start for Grid System Operator (GSO) for grid flexibility and reliability $[78,79]$. For utility services, BESS is capable of transmission congestion relief and as an alternative for Transmission and Distribution deferral. For behind the meter (BTM) services, BESS can be used for back-up power, peak demand reduction, energy arbitrage, and increased PV solar self-consumption [80,81].

In Malaysia, BESS for behind the meter and VPP project have been deployed as research projects. However, for utility-scale batteries, there has not been any deployment yet. The main challenge in deploying such projects is the high capital cost. BNEF has projected a significant drop in capital costs for BESS, estimated at $5 \%$ decrease yearly. However, without proper incentives and regulations from the Government, commercial projects for BESS will remain a challenge.

South Korean provides an example of a high deployment of BESS projects. Since 2011, the Korean government has implemented $500 \mathrm{MW}$ of frequency regulation BESS. This is supported by its generous multiple in the Renewable Energy Certificate (REC) [82]. Figure 6 shows the capital cost for 20 MW/80 MWh Fully-installed BESS and the projection price up until the year 2030.

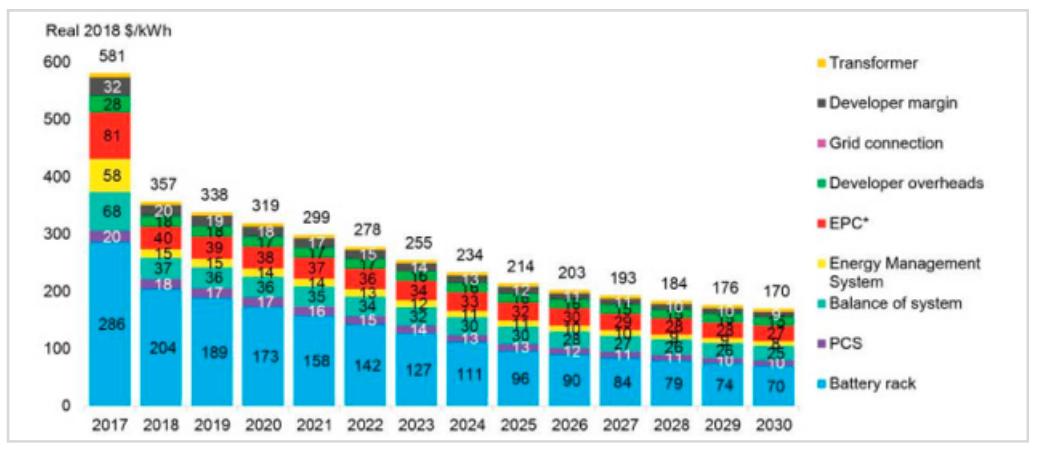

Figure 6. Capital cost for $20 \mathrm{MW} / 80 \mathrm{MWh}$ fully-installed BESS. Reproduced with permission from [83]. Bloomberg New Energy Finance, 2018.

\section{Policies and Incentives}

Malaysia has embarked into several key initiatives on RE. Some of these started way back in 1997 when Malaysia signed for Kyoto protocol and committed to reduce greenhouse gas emission. In 1999 Malaysia announced the Fifth-fuel strategy where RE is the alternative power generation besides the four previous fuel sources, namely oil, gas, coal and hydro [32,84,85]. In 2008, Malaysia embraced on Energy Efficiency (EE) by launching the Efficient Management Of Electrical Energy Regulations (EMEER) 2008 [86]. In the following year, Malaysia pledged to COP 15 where the county committed to reduce carbon intensity by $40 \%$. The biggest impact on the RE market was when FiT scheme was introduced back in 2011. This incentive was based on a quota and managed by SEDA. This scheme incentivized RE developers with a premium tariff rate.

The Net Energy Metering (NEM) mechanism has also been deployed successfully. It has been revised to have more attractive rates. With this new mechanism, customers with roof top solar will enjoy better electricity savings. Recently, the Government has also announced that the national RE target has been revised to a more aggressive target, to reach $20 \%$ of RE penetration by the year 2025 . Approximately $50 \%$ of the target will be coming from solar technology while another $50 \%$ will come 
from non-solar technologies. Solar technology is considered the easiest RE technology to be deployed and also the low price that can be offered by solar makes it even more attractive. The other non-solar technologies need strong support from the Government in terms of incentives to ensure project viability.

\section{Key Challenges}

Key challenges for RE deployment in Malaysia will be discussed in terms of technical, economic and social perspectives. Technically, the key success criteria are to suit the selected technology based on the actual resources in Malaysia, for instance, the wind technology selected should be for low wind conditions, as Malaysia has a low wind resources compared to other countries. For the kind of technologies which are still in early stages of deployment in Malaysia, e.g. biogas and BESS, they must be supported by research projects or small-scale pilot projects to determine the actual suitability to Malaysian conditions.

Most of the challenges will be coming from commercial perspectives. RE as a new energy resource for Malaysia requires high investment values. Incentives from the Government are very important at the initial stage of deployment. The FiT mechanism seems to be working in terms of implementation but the rates might not be sufficient for some technologies after considering all other risks. For example, for mini hydro projects, compensations to Aboriginal communities and other affected communities can impact the total project cost. FiT for biogas generation from municipal solid waste (MSW) or food waste should be revised to allocate specific FiT allocation for this type of technology, as this technology can be a solution to the existing problem to treat MSW and to prolong the life of landfills in this country.

In terms of social, challenges could be seen from the perspective of procuring land especially for big projects such as large hydro and large scale solar. Large hydro will impact the surrounding community and also have other environmental effects due to large dam construction. Support from the local community is essential for all types of project construction to mitigate the 'not in my back yard' (NIMBY) syndrome.

\section{Conclusions}

In conclusion, Malaysia is blessed with an abundance of potential for Renewable Energy, including solar, wind, hydro, biogas, and biomass. Geothermal was not discussed in this paper as Malaysia based on its geographical condition has very limited geothermal resources. For tidal energy, Malaysia has less resources compared to other countries. The ideal current speed to achieve the maximum potential of the turbine to generate a substantial amount of energy is $2 \mathrm{~m} / \mathrm{s}$ (4 knots) while average current velocity in Malaysia is only at $1 \mathrm{~m} / \mathrm{s}$ ( 2 knots). Both forms of technology are still in very early stages of research as limited studies were found in these areas.

In order for the government to reach the RE capacity penetration target, it must be aggressively supported by Government incentives and proper alignment in terms of government policies and implementation [24,25,32-34,87]. For instance, for biogas technology, enforcement in terms of waste separation can be the enabler of the successful deployment of this technology. For hydropower and BESS, as these developments are capital intensive, government incentives will boost technology deployment. For wind power deployment, Malaysia has to explore by using suitable technology for low wind condition as geographically Malaysia is located in an area that is relatively low in terms of wind speed. For large scale solar, as this technology is quite mature, Malaysia can consider developing solar parks to boost the deployment rate. Finally, on the future for conventional generation, Malaysia will be still depending on coal and natural gas generation but with a higher penetration of $\mathrm{RE}$, the conventional plants will potentially be changing role from base load to standby generation sources as RE penetration increases in the system.

With the information provided in this paper, more research projects and commercially driven projects can be initiated. This will help to expedite RE deployment projects in line with the Malaysian Government to achieve 20\% RE penetration by 2025. 
Author Contributions: Conceptualization, W.S.W.A. and M.Z.A.A.K.; methodology, W.S.W.A.; formal analysis, W.S.W.A.; investigation, W.S.W.A.; resources, W.S.W.A.; data curation, W.S.W.A.; writing-original draft preparation, W.S.W.A.; writing-review and editing, W.S.W.A., M.O., R.V.; supervision, M.Z.A.A.K., M.O., R.V.; funding acquisition, M.O.

Funding: This research received funding from UNITEN BOLD Publication Fund.

Acknowledgments: The authors would like to express their gratitude to Tenaga Nasional Berhad (TNB) for the data and information to conduct the research study and Universiti Tenaga Nasional (UNITEN), Malaysia for the financial support through UNITEN BOLD publication fund.

Conflicts of Interest: The authors declare no conflict of interest.

\section{References}

1. Renewable Energy Policy Network for the 21st Century. Renewables 2018 Global Status Report; Renewable Energy Policy Network for the 21st Century: Paris, France, 2018.

2. Sharvini, S.R.; Noor, Z.Z.; Chong, C.S.; Stringer, L.C.; Yusuf, R.O. Energy consumption trends and their linkages with renewable energy policies in East and Southeast Asian countries: Challenges and opportunities. Sustain. Environ. Res. 2018, 28, 257-266. [CrossRef]

3. Hossein, M.; Ashnani, M.; Johari, A.; Hashim, H. A source of renewable energy in Malaysia, why biodiesel? Renew. Sustain. Energy Rev. 2014, 35, 244-257.

4. Dahlan, N.Y.; Ibrahim, A.; Rajemi, F.M.; Nawi, M.N.M.; Baharum, F. Analysis of the impact of nuclear power plant on Malaysia's power systems: Costs, $\mathrm{CO}_{2}$ emission and system reliability. In Proceedings of the 2014 IEEE International Conference on Power and Energy (PECon), Kuching, Malaysia, 1-3 December 2014; pp. 206-211. [CrossRef]

5. Saad, S.M.A.; Ismail, F.A.; Fauzi, F.M.; Rahmat, M.K. Consideration for nuclear energy in Malaysia. In Proceedings of the 2017 International Conference on Engineering Technology and Technopreneurship (ICE2T), Kuala Lumpur, Malaysia, 18-20 September 2017; pp. 1-5. [CrossRef]

6. Mutalib, N.A.H.A.; Dahlan, N.Y.; Abon, S.A.; Rajemi, M.F.; Nawi, M.N.M.; Baharum, F. Optimum generation mix for Malaysia's additional capacity using evolutionary programming. In Proceedings of the 2014 IEEE International Conference on Power and Energy (PECon), Kuching, Malaysia, 1-3 December 2014; pp. 65-70. [CrossRef]

7. Lim, X.; Lam, W. Public Acceptance of Marine Renewable Energy in Malaysia. Energy Policy 2014, 65, 16-26. [CrossRef]

8. Ali, H.; Salwati, N. The role of renewable energy to validate dynamic interaction between $\mathrm{CO}_{2}$ emissions and GDP toward sustainable development in Malaysia. Energy Econ. 2018, 72, 47-61.

9. Rahman, M.S.; Noman, A.H.M.; Shahari, F. Does economic growth in Malaysia depend on disaggregate energy? Renew. Sustain. Energy Rev. 2017, 78, 640-647. [CrossRef]

10. Petinrin, J.O.; Shaaban, M. Renewable energy for continuous energy sustainability in Malaysia. Renew. Sustain. Energy Rev. 2015, 50, 967-981. [CrossRef]

11. Daut, I.; Irwanto, M.; Irwan, Y.M.; Gomesh, N.; Rosnazr, N.S.A. Potential of Solar Radiation and Wind Speed for Photovoltaic and Wind Power Hybrid Generation in Perlis, Northern Malaysia. In Proceedings of the 2011 5th International Power Engineering and Optimization Conference, Shah Alam, Malaysia, 6-7 June 2011; pp. 148-153. [CrossRef]

12. Subramaniam, T.; Safwan, M.; Rahman, A. An Investigation on the Power System Stability of Photovoltaic Grid Integrated System. In Proceedings of the 2017 7th IEEE International Conference on Control System, Computing and Engineering (ICCSCE), Penang, Malaysia, 24-26 November 2018; pp. 24-26. [CrossRef]

13. Mekhilef, S.; Barimani, M.; Safari, A.; Salam, Z. Malaysia's renewable energy policies and programs with green aspects. Renew. Sustain. Energy Rev. 2014, 40, 497-504. [CrossRef]

14. Eusoff, N.S. Malaysia Sets New Goal of 20\% Clean Energy Generation by 2025; The Edge Markets: Kuala Lumpur, Malaysia, 2018; pp. 1-8.

15. Energy Commission of Malaysia. Peninsular Malaysia Electric Supply Outlook 2017; Energy Commission of Malaysia: Kuala Lumpur, Malaysia, 2017.

16. Malaysia Gas Instituition. Natural Gas Industry Annual Review; Malaysia Gas Institution: Kuala Lumpur, Malaysia, 2017. 
17. Malaysia Energy Commission. Electricity Tariff Review in Peninsular Malaysia for Regulatory Period 2 (RP2: 2018-2020) under Incentive-Based Regulation (IBR). Mechanism 2018, 2, 42.

18. Ahmad, S.; Kadir, M.Z.A.A.; Shafie, S. Current perspective of the renewable energy development in Malaysia. Renew. Sustain. Energy Rev. 2011, 15, 897-904. [CrossRef]

19. Ong, H.C.; Mahlia, T.M.I.; Masjuki, H.H. A review on energy scenario and sustainable energy in Malaysia. Renew. Sustain. Energy Rev. 2011, 15, 639-647. [CrossRef]

20. Tang, S.; Chen, J.; Sun, P.; Li, Y.; Yu, P.; Chen, E. Current and future hydropower development in Southeast Asia countries (Malaysia, Indonesia, Thailand and Myanmar). Energy Policy 2019, 129, 239-249. [CrossRef]

21. Mohibullah, M.; Radzi, A.M.; Hakim, M.I. Basic design aspects of micro hydro power plant and its potential development in Malaysia. In Proceedings of the National Power and Energy Conference, Kuala Lumpur, Malaysia, 29-30 November 2004; pp. 220-223. [CrossRef]

22. Hossain, M.; Huda, A.S.N.; Mekhilef, S.; Seyedmahmoudian, M.; Horan, B.; Stojcevski, A.; Ahmed, M. A state-of-the-art review of hydropower in Malaysia as renewable energy: Current status and future prospects. Energy Strateg. Rev. 2018, 22, 426-437. [CrossRef]

23. International Hydropower Association. Hydropower Status Report. Available online: https://www.hydroworld.com/content/dam/hydroworld/online-articles/2017/08/2017\%20Hydropower\% 20Status\%20Report-1.pdf (accessed on 20 April 2019).

24. Kardooni, R.; Yusoff, S.B.; Kari, F.B.; Moeenizadeh, L. Moeenizadeh. Public opinion on renewable energy technologies and climate change in Peninsular Malaysia. Renew. Energy 2048, 116, 659-668. [CrossRef]

25. Hannan, M.A.; Begum, R.A.; Abdolrasol, M.G.; Lipu, M.S.H.; Mohamed, A.; Rashid, M.M. Review of baseline studies on energy policies and indicators in Malaysia for future sustainable energy development. Renew. Sustain. Energy Rev. 2018, 94, 551-564. [CrossRef]

26. Shaikh, P.H.; Nor, N.B.M.; Sahito, A.A.; Nallagownden, P.; Elamvazuthi, I.; Shaikh, M.S. Building energy for sustainable development in Malaysia: A review. Renew. Sustain. Energy Rev. 2017, 75, 1392-1403. [CrossRef]

27. Energy Commission. Energy in Malaysia. Available online: https://www.st.gov.my/ms/contents/publications/ energyMalaysia/EM12\%20Nov\%202017\%20v2.pdf (accessed on 15 April 2019).

28. Xin, A.; Shin, W.; Phun, C.; Hassim, M.; Liew, P.; Asli, U.; Kamaruddin, J.; Chemmanggattuvalappil, N. Review of hydrogen economy in Malaysia and its way forward. Int. J. Hydrog. Energy 2019, 1-15.

29. Kardooni, R.; Binti, S.; Binti, F. Renewable energy technology acceptance in Peninsular Malaysia. Energy Policy 2016, 88, 1-10. [CrossRef]

30. Lim, X.; Lam, W.; Hashim, R. Feasibility of marine renewable energy to the Feed-in Tariff system in Malaysia. Renew. Sustain. Energy Rev. 2015, 49, 708-719. [CrossRef]

31. Palanisamy, K. Anaerobic Digester on Food Waste Seminar Anaerobic Co-Digestion of Sewage to Produce Biogas for Electricity; Universiti Tenaga Nasional: Kajang, Malaysia, 2018.

32. Maulud, A.L.; Saidi, H. The Malaysian Fifth Fuel Policy: Re-strategising the Malaysian Renewable Energy Initiatives. Energy Policy 2012, 48, 88-92. [CrossRef]

33. Chatri, F.; Yahoo, M.; Othman, J. The economic effects of renewable energy expansion in the electricity sector: A CGE analysis for Malaysia. Renew. Sustain. Energy Rev. 2018, 95, 203-216. [CrossRef]

34. Oh, T.H.; Hasanuzzaman, M.; Selvaraj, J.; Teo, S.C.; Chua, S.C. Energy policy and alternative energy in Malaysia: Issues and challenges for sustainable growth-An update. Renew. Sustain. Energy Rev. 2018, 81, 3021-3031. [CrossRef]

35. Mekhilef, S.; Safari, A.; Mustaffa, W.E.S.; Saidur, R.; Omar, R.; Younis, M.A.A. Solar energy in Malaysia: Current state and prospects. Renew. Sustain. Energy Rev. 2012, 16, 386-396. [CrossRef]

36. Gomesh, N.; Daut, I.; Irwanto, M.; Irwan, Y.M.; Fitra, M. Study on Malaysian's Perspective towards Renewable Energy Mainly on Solar Energy. Energy Procedia 2013, 36, 303-312. [CrossRef]

37. Mansur, T.M.N.T.; Baharudin, N.H.; Ali, R. Technical and Economic Analysis of Net Energy Metering for Residential House. Indones. J. Electr. Eng. Comput. Sci. 2018, 11, 585-592. [CrossRef]

38. Mansur, T.M.N.T.; Baharudin, N.H.; Ali, R. Performance Analysis of Self-Consumed Solar PV System for A Fully DC Residential House. Indones. J. Electr. Eng. Comput. Sci. 2017, 8, 391-398. [CrossRef]

39. Wahid, S.A.; Nawawi, Z.; Jambak, M.I.; Arief, Y.Z.; Sidik, M.A.B.; Mustafa, M.W.; Adzis, Z. Evaluation of Residential Grid-Connected Photovoltaic System as the Potential Energy Source in Malaysia. Telkomnika 2016, 14, 1235. [CrossRef] 
40. Mansur, T.M.N.T.; Baharudin, N.H.; Ali, R. Sizing and Cost Analysis of Self-Consumed Solar PV DC System Compared with AC System for Residential House. Indones. J. Electr. Eng. Comput. Sci. 2018, 10, 10. [CrossRef]

41. Barai, G.R.; Krishnan, S.; Venkatesh, B. Smart metering and functionalities of smart meters in smart grid-A review. In Proceedings of the 2015 IEEE Electrical Power Energy Conferences Marter Resilient Power Systems EPEC, London, ON, Canada, 26-28 October 2015; pp. 138-145. [CrossRef]

42. Yeung, B.Y.P.; Jung, M. Improving Electric Reliability with Smart Meters Tool to Improve Grid Reliability for Utility Customers; Silver Spring Network: San Jose, CA, USA, 2013.

43. Tenaga Nasional Berhad Annual Report 2017. Shaping the Energy Landscape. Available online: https://www.tnb.com.my/assets/annual_report/TNB_AR2017_4MONTH_PERIOD_ENDED_31_ DECEMBER_2017.pdf (accessed on 15 April 2019).

44. Islam, M.R. Assessment of Wind Energy Potential Mapping for Peninsular Malaysia; University of Malaya: Kuala Lumpur, Malaysia, 2011; pp. 89-95.

45. Zaharim, A.; Mat, S.; Sopian, K.; Jedi, A.; Masseran, N.; Safari, M.A.M. The Impact of Wind Technology Among Rural Community in Mersing Malaysia. In Proceedings of the 2017 International Conference in Energy and Sustainability in Small Developing Economies (ES2DE), Funchal, Portugal, 10-12 July 2017; pp. 1-16. [CrossRef]

46. Ibrahim, M.Z.; Hwang, Y.K.; Ismail, M.; Albani, A. Spatial Analysis of Wind Potential for Malaysia. Int. J. Renew. Energy Res. 2015, 5, 201-209.

47. Muda, W.M.W.; Salleh, N.A.S. Feasibility Study of Renewable Energy System for an Island in Terengganu. IOP Conf. Ser. Mater. Sci. Eng. 2018, 366, 012002. [CrossRef]

48. Ibrahim, M.Z.; Yong, K.H.; Ismail, M.; Albani, A.; Muzathik, A.M. Wind characteristics and gis-based spatial wind mapping study in Malaysia. J. Sustain. Sci. Manag. 2014, 9, 1-20.

49. Izzah, N.; Aziz, H.A.; Hana, M.M.; Gheewala, S.H. Biomass and Bioenergy A review on life cycle assessment of biogas production: Challenges and future perspectives in Malaysia. Biomass Bioenergy 2019, 122, 361-374.

50. Siddique, M.N.I.; Wahid, Z.A. Achievements and perspectives of anaerobic co-digestion: A review. J. Clean. Prod. 2018, 194, 359-371. [CrossRef]

51. Siddique, M.B.M.; Kashem, S.B.A.; Iqbal, A. Biofuels in Malaysian perspective: Debates and benefits. In Proceedings of the 2018 IEEE 12th International Conference on Compatibility, Power Electronics and Power Engineering (CPE-POWERENG 2018), Doha, Qatar, 10-12 April 2018; pp. 1-6.

52. Rojas, I.R.; Vasquez, L.I. Energy Generation from Solid Waste. A Literature Review. In Proceedings of the 2018 Congreso Internacional de Innovación y Tendencias en Ingeniería (CONIITI), Bogota, Colombia, 3-5 October 2018; pp. 1-4.

53. Budzianowski, W.M.; Budzianowska, D.A. Economic analysis of biomethane and bioelectricity generation from biogas using different support schemes and plant configurations. Energy 2015, 88, 658-666. [CrossRef]

54. Nor, M.F.M.; Hassan, S.; Said, M.A.; Aris, M.S. Investigation of Fuel Characterisation of Waste Sludge from Sewage Treatment Plants (STP). MATEC Web Conf. 2018, 225, 04019. [CrossRef]

55. Hoo, P.Y.; Hashim, H.; Ho, W.S. Opportunities and challenges: Landfill gas to biomethane injection into natural gas distribution grid through pipeline. J. Clean. Prod. 2018, 175, 409-419. [CrossRef]

56. Arij, Y.; Fatihah, S.; Rakmi, A.R. Performance of pilot scale anaerobic biofilm digester (ABD) for the treatment of leachate from a municipal waste transfer station. Bioresour. Technol. 2018, 260, 213-220. [CrossRef]

57. Loh, S.K. The potential of the Malaysian oil palm biomass as a renewable energy source. Energy Convers. Manag. 2017, 141, 285-298. [CrossRef]

58. Phun, C.; Bong, C.; Shin, W.; Hashim, H.; Shiun, J. Review on the renewable energy and solid waste management policies towards biogas development in Malaysia. Renew. Sustain. Energy Rev. 2017, 70, 988-998.

59. Ehsan, S.; Wahid, M.A. Feasibility study of biogas production and utilization as a source of renewable energy in Malaysia. Renew. Sustain. Energy Rev. 2013, 19, 454-462.

60. Yoo, H.M.; Park, S.W.; Seo, Y.C.; Kim, K.H. Applicability assessment of empty fruit bunches from palm oil mills for use as bio-solid refuse fuels. J. Environ. Manag. 2019, 234, 1-7. [CrossRef]

61. Jaye, I.M.; Sadhukhan, J.; Murphy, R.J. Murphy. Integrated Assessment of Palm Oil Mill Residues to Sustainable Electricity System (POMR-SES): A Case Study from Peninsular Malaysia. IOP Conf. Ser. Mater. Sci. Eng. 2018, 358, 012002. [CrossRef] 
62. Aziz, N.I.H.A.; Hanafiah, M.M. Anaerobic digestion of palm oil mill effluent (POME) using bio-methane potential (BMP) test. AIP Conf. Proc. 2018, 1940, 020026.

63. Aziz, N.I.H.A.; Hanafiah, M.M.; Ali Mohamed, M.Y. Sustainable biogas production from agrowaste and effluents-A promising step for small-scale industry income. Renew. Energy 2019, 132, 363-369. [CrossRef]

64. Loh, S.K.; Nasrin, A.B.; Azri, S.M.; Adela, B.N.; Muzzammil, N.; Jay, T.D.; Eleanor, R.S.; Lim, W.S.; Choo, Y.M.; Kaltschmitt, M. First Report on Malaysia's experiences and development in biogas capture and utilization from palm oil mill effluent under the Economic Transformation Programme: Current and future perspectives. Renew. Sustain. Energy Rev. 2017, 74, 1257-1274. [CrossRef]

65. Gopinathan, M.; Kumaran, P.; Rahaman, A.A.; bt Ismail, Z. Progress of Biogas Industry in Malaysia: Cattle Manure as Potential Substrate for Biogas production and Issue and Challenges. In Proceedings of the 2018 International Conference and Utility Exhibition on Green Energy for Sustainable Development (ICUE), Phuket, Thailand, 24-26 October 2018.

66. Del Zotto, L.; Tallini, A.; Di Simone, G.; Molinari, G.; Cedola, L. Energy enhancement of Solid Recovered Fuel within systems of conventional thermal power generation. Energy Procedia 2015, 81, 319-338. [CrossRef]

67. Ozturk, M.; Saba, N.; Altay, V.; Iqbal, R.; Hakeem, K.R.; Jawaid, M.; Ibrahim, F.H. Biomass and bioenergy: An overview of the development potential in Turkey and Malaysia. Renew. Sustain. Energy Rev. 2017, 79, 1285-1302. [CrossRef]

68. Verma, M.; Loha, C.; Sinha, A.N.; Chatterjee, P.K. Drying of biomass for utilising in co-firing with coal and its impact on environment-A review. Renew. Sustain. Energy Rev. 2017, 71, 732-741. [CrossRef]

69. Union of Concerned Scientists. Cattle, Cleared Forests, and Climate Change: Scoring America's Top Brands on Their Deforestation-Free Beef Commitments and Practices; Union of Concerned Scientists: Cambridge, UK, 2016; p. 18.

70. Sustainable Energy Development Authority. Annual Power Generation (MWh) of Commissioned RE Installations; Sustainable Energy Development Authority: Kuala Lumpur, Malaysia, 2019; p. 2019.

71. Abdullah, J.O.S.; Azrulhisham, E.A.; Juhari, M. Exploring Malaysia's Small Hydro Potential; Hydro Review Worldwide: Tulsa, OH, USA, 2016.

72. Raman, N.; Hussein, I.; Palanisamy, K. Micro hydro potential in West Malaysia. In Proceedings of the 2009 3rd International Conference on Energy and Environment (ICEE), Malacca, Malaysia, 7-8 December 2009; pp. 348-359. [CrossRef]

73. Yah, N.F.; Oumer, A.N.; Idris, M.S. Small scale hydro-power as a source of renewable energy in Malaysia: A review. Renew. Sustain. Energy Rev. 2017, 72, 228-239. [CrossRef]

74. Mcpherson, M.; Tahseen, S. Deploying storage assets to facilitate variable renewable energy integration: The impacts of grid fl exibility, renewable penetration, and market structure. Energy 2018, 145, 856-870. [CrossRef]

75. Lucas, A.; Chondrogiannis, S. Smart grid energy storage controller for frequency regulation and peak shaving, using a vanadium redox flow battery. Int. J. Electr. Power Energy Syst. 2016, 80, 26-36. [CrossRef]

76. Akinyele, D.O.; Rayudu, R.K. Review of energy storage technologies for sustainable power networks. Sustain. Energy Technol. Assess. 2014, 8, 74-91. [CrossRef]

77. Salim, N.B.; Khamis, A.B.; Nazmin, A.N.B.; Zambri, N.A.B. Frequency Control Reserve via Micro Grid for the Future Renewable Malaysian Power System. In Proceedings of the 2018 IEEE PES Asia-Pacific Power and Energy Engineering Conference (APPEEC), Kota Kinabalu, Malaysia, 7-10 October 2018; pp. 428-433.

78. Jing, W.; Lai, C.H.; Ling, D.K.; Wong, W.S.; Wong, M.D. Battery lifetime enhancement via smart hybrid energy storage plug-in module in standalone photovoltaic power system. J. Energy Storage 2019, 21, 586-598. [CrossRef]

79. Wen, Y.; Kittner, N.; Kammen, D.M. ASEAN grid flexibility: Preparedness for grid integration of renewable energy. Energy Policy 2019, 128, 711-726.

80. Koohi-Kamali, S.; Rahim, N.A.; Mokhlis, H. Coordinated Control of Smart Microgrid Considering Variability in Load Demand and Generation. In Proceedings of the 4th IET Clean Energy and Technology Conference (CEAT 2016), Kuala Lumpur, Malaysia, 14-15 November 2016; Volume 7.

81. Khan, M.R.B.; Pasupuleti, J.; Al-Fattah, J.; Tahmasebi, M. Tahmasebi. Optimal Grid-Connected PV System for a Campus Microgrid. Indones. J. Electr. Eng. Comput. Sci. 2018, 12, 899-906. [CrossRef]

82. Bloomberg New Energy Finance. Global Energy Storage Policy Review Part 2-Case Studies; Bloomberg New Energy Finance: Manhattan, NY, USA, 2019. 
83. Bloomberg New Energy Finance. 2018 Long Term Energy Storage Outlook; Bloomberg New Energy Finance: Manhattan, NY, USA, 2018.

84. Chaudhry, P.; Tewari, V.P. Environmental education using Nek Chand's Rock Garden in the City of Chandigarh. Int. J. Environ. Sustain. Dev. 2010, 9, 30. [CrossRef]

85. Ahmad Zaman, A.A.; Hashim, F.E.; Yaakob, O. Satellite-Based Offshore Wind Energy Resource Mapping in Malaysia. J. Mar. Sci. Appl. 2019, 18, 114-121. [CrossRef]

86. Energy Commission. Enhancing Energy Efficiency in Malaysia through Legislation and Policy; Energy Commission: Kuala Lumpur, Malaysia, 2016; pp. 1-35.

87. Khuong, P.M.; Mckenna, R.; Fichtner, W. Analyzing drivers of renewable energy development in Southeast Asia countries with correlation and decomposition methods. J. Clean. Prod. 2019, 213, 710-722. [CrossRef]

C 2019 by the authors. Licensee MDPI, Basel, Switzerland. This article is an open access article distributed under the terms and conditions of the Creative Commons Attribution (CC BY) license (http://creativecommons.org/licenses/by/4.0/). 